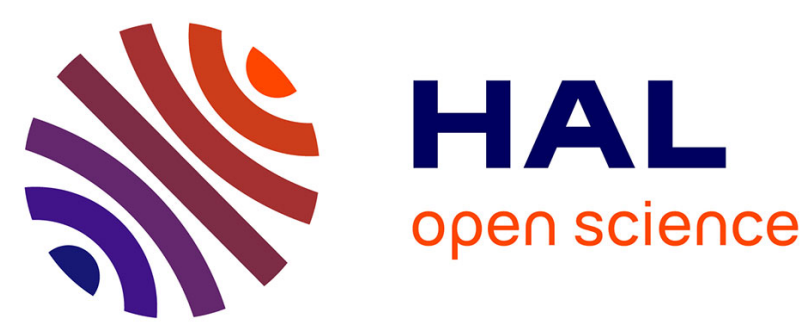

\title{
CONTACT, TRUST AND SOCIAL CAPITAL IN NORTHERN IRELAND: A QUALITATIVE STUDY OF THREE MIXED COMMUNITIES
}

Andrea Campbell, Joanne Hughes, Richard Jenkins

\section{- To cite this version:}

Andrea Campbell, Joanne Hughes, Richard Jenkins. CONTACT, TRUST AND SOCIAL CAPITAL IN NORTHERN IRELAND: A QUALITATIVE STUDY OF THREE MIXED COMMUNITIES. Ethnic and Racial Studies, 2010, PP (PP), pp.1. 10.1080/01419870.2010.526234 . hal-00643461

\section{HAL Id: hal-00643461 \\ https://hal.science/hal-00643461}

Submitted on 22 Nov 2011

HAL is a multi-disciplinary open access archive for the deposit and dissemination of scientific research documents, whether they are published or not. The documents may come from teaching and research institutions in France or abroad, or from public or private research centers.
L'archive ouverte pluridisciplinaire HAL, est destinée au dépôt et à la diffusion de documents scientifiques de niveau recherche, publiés ou non, émanant des établissements d'enseignement et de recherche français ou étrangers, des laboratoires publics ou privés. 


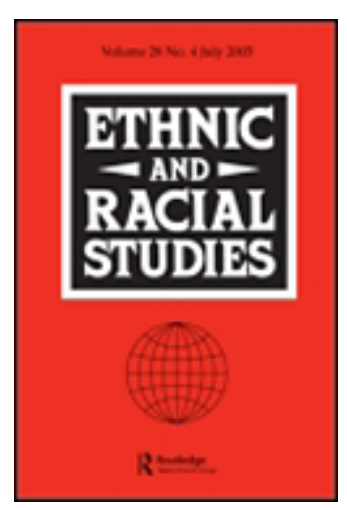

\section{CONTACT, TRUST AND SOCIAL CAPITAL IN NORTHERN \\ IRELAND: A QUALITATIVE STUDY OF THREE MIXED COMMUNITIES}

\begin{tabular}{|r|l|}
\hline Journal: & Ethnic and Racial Studies \\
\hline Manuscript ID: & RERS-2009-0162.R3 \\
\hline Manuscript Type: & Original Manuscript \\
\hline Keywords: & $\begin{array}{l}\text { Ethnic Conflict, Ethnic Relations, Social Capital, social networks, } \\
\text { Collective Identity, Conflict }\end{array}$ \\
\hline \multicolumn{2}{|l}{} \\
\hline
\end{tabular}

\section{SCHOLARONE" Manuscripts}


In a recent paper, Robert Putnam (2007) challenges the contact hypothesis by arguing that ethnic diversity causes people to 'hunker down' and essentially withdraw themselves from society. Drawing on qualitative data collected from three mixed communities in Northern Ireland, this paper explores the extent and quality of contact experienced by Protestants and Catholics in their everyday lives. Themes emerging from our data are generally consistent with the contact hypothesis. There is also some support for Putnam's theory that mixed environments can induce 'hunkering down' and that inter-group trust may be compromised. However, our data challenge Putnam's argument that these responses are a consequence of 'anomie' or 'social malaise'. Rather, we find that withdrawal from social activity in the neighbourhoods we observed was a calculated response at times of threat, often aimed at protecting existent positive inter-ethnic relations.

\section{KEYWORDS}

Ethnic conflict, Ethnic relations, Social capital, Social networks, Collective identity, Conflict 
More than a decade has passed since the historic 1998 Belfast/Good Friday Peace Agreement. Supported by the majority of residents in Northern Ireland, the Agreement was viewed by many as signifying the beginning of a more peaceful era in a jurisdiction that had endured more than thirty years of violent conflict. In addition to outlining the systematic steps needed for paramilitary decommissioning and the reestablishment of a power sharing Executive (McAuley and Tonge 2009), the Agreement intended to embed an ethos of cultural recognition, respect, and tolerance in both intercommunity and interstate relations.

Despite these macro-level developments, sectarian conflict remains a problem (Community Relations Council, 2010) and segregation between Protestants and Catholics is a persistent feature of life in Northern Ireland. Today, more than ninety percent of children attend separate schools, and it is estimated that approximately $35-40$ percent of the population live in completely segregated neighborhoods (see Hewstone et al. 2004). The possibility that the residential and social separation of the two main communities in Northern Ireland may contribute to inter-group tensions has long been recognized (Shirlow 2003). Darby, for example, has postulated that there might have been many more deaths, were it not for opportunities that exist in Northern Ireland for Protestants and Catholics to meet and forge relationships (1990).

Consistent with the contact hypothesis, first developed by Gordon Allport in 1954, Darby refers to 'controlled contact' (where Protestants and Catholics interact whilst retaining own group allegiance) and 'functional integration' (where members of the two groups work together in pursuit of common 
objectives) as conflict attenuating mechanisms that 'reduce and manage the effects of sectarian differences' (1990, p.5).

Endorsing the value of contact, and juxtaposed with efforts to reach the political settlement that culminated in the signing of the Belfast/Good Friday Agreement, a central plank of Direct Rule government effort during the conflict years was a community relations policy agenda that aimed to tackle the problems of sectarianism and division through the promotion of greater inter-ethnic contact (for a review see, for example, Knox and Hughes 1996).

Cross-community contact work has not, however, been without its detractors. A prevailing view is that it tackles the symptoms of conflict, such as segregation and division, rather than conflict's root causes, such as structural inequality and disadvantage (Hughes and Donnelly 2003). Reflecting this concern, progress on reaching political consensus on a policy for relationship building in the wake of the Belfast/Good Friday Agreement has been slow. As the current Northern Ireland Executive seeks to deal with the legacy of the conflict and ongoing sectarianism, the debate about how best to resolve the problems of division has been beset by disagreement between the main political parties as to its causes (Knox 2008). This has apparently contributed to a long delay in the release of a policy for 'Cohesion, Sharing and Integration', promised in the Northern Ireland Executive's Programme for Government (2008).

Concurrent with some soul searching in Northern Ireland about the value to community relations of contact, the value of contact in generating more positive inter-ethnic attitudes has been challenged in a recent study by Putnam (2007). The paradigm-shaking results of this study suggest that there are significantly lower levels of social trust in ethnically diverse neighborhoods, 
compared to more homogeneous communities. Against this background, and in the current policy hiatus in Northern Ireland, this paper draws on qualitative research to explore the issue of contact and trust in three heterogeneous communities in Northern Ireland.

\section{Contact Theory}

The Contact Hypothesis proposed by Allport (1954), maintains that interaction between two opposing groups under optimal conditions should lead to reduced prejudice. Specifically, Allport delineated four key prerequisites in order for optimal contact to occur. First, there should be equal status among the groups, who meet. Secondly, the situation in which inter-ethnic contact occurs should require co-operation between groups or offer common goals to both groups. Thirdly, cooperation between the groups involved should be encouraged. Lastly, the contact situation should be legitimized through institutional support.

As contact theory has evolved, attention has moved from establishing conducive conditions to a focus on identifying the mediational (why contact works) and moderational (when contact works) mechanisms involved in successful inter-ethnic contact. Five key mediating processes have been suggested, involving functional relations between groups, behavioural responses, affective reactions to out-group members, and the two cognitive factors of 'learning new information' and 'social representation' (Dovidio, Gaertner and Kawakami 2003). According to Dovidio et al. Allport's aforementioned optimal conditions, along with personal interaction and friendship, generate these five mediational processes, which in turn lead to a reduction in stereotyping and more positive other-group attitudes. Within this framework, these attitudes are 
generalised from an individual to the other group as a whole with both cognitive and affective factors regarded as contributing to generalisation.

In relation to moderating mechanisms, research suggests that group salience is an essential part of whatever it is that causes the effects of inter-ethnic contact. There is a general consensus in the literature that, in order for contact effects to generalise from the individuals experiencing contact to the other group as a whole, the salience of group membership must be maintained during a contact situation (Hewstone and Brown 1986). Conversely, however, the salience of group membership tends to be associated with negative emotions such as fear, anxiety, and discomfort (Stephan and Stephan 1985). In an attempt to eliminate potential negative effects of contact, Pettigrew (1998), suggests that category salience should only be increased over time: interpersonal interaction should take precedence, followed by increased category salience and the subsequent positive generalisation of other-group members. Pettigrew also suggests a third step, involving re-categorization, in which group memberships are replaced by a common own group identity (cf. Gaertner et al. 1993) or dual identity (Gaertner and Dovidio 2000). However, the most valuable contribution of Pettigrew's 3-stage approach (1998) may be the emphasis he placed on crossethnic friendships: repeated contact with an other-group friends, involving affective ties and self-disclosure, facilitates the development of his three stages (Paolini et al. 2004).

\section{Conflict Theory and Putnam}

Conflict theory, in direct opposition to contact theory, argues that other-group attitudes and prejudices are so deeply ingrained that contact inevitably leads to 
inter-ethnic conflict. More specifically, according to the theory, diversity fosters other-group distrust and own-group solidarity. In a recent article on diversity and community, Robert Putnam (2007) suggests that most empirical research appears to support conflict theory, and cites evidence from a variety of countries and settings indicating a negative relationship between diversity and solidarity. In addition, however, he argues that diversity is not only associated with lower levels of other-group trust but that it also impacts negatively upon own-group trust. He argues that diversity seems to activate a sense of anomie or social isolation within communities causing people to 'hunker down' and withdraw from society. Putnam calls this perspective 'constrict theory' and adduces a significant amount of evidence in its support. For example, he argues that there is an association between a lack of social trust and systematically lower confidence in political leaders, news media, and government and so on. In addition, he suggests that in diverse communities people tend to avoid social life, participate in fewer civic organisations, and feel more helpless within their communities. In sum, heterogeneity lowers trust, at least in the short to medium term (Putnam 2007).

Putnam's research findings derive from his analysis of data from the Social Capital Community Benchmark Survey. The survey, conducted in 2000, involved a sample of approximately 30,000 people, representing an amalgamation of a national sample of 3000 and a community-level sample representative of 41 distinctive communities across the United States. These communities ranged in size from small rural areas and towns to large metropolitan centres, with huge disparity in their ethic diversity. The survey was 
conducted simultaneously with the 2000 census, which enabled Putnam to match each respondent to census tract and community characteristics.

Putnam's findings have, however, been criticised on a number of grounds. For example, in a recent critique Dawkins (2008) points to the methodological and conceptual limitations of the study. Among his primary concerns are the failure to distinguish between diversity and residential segregation, potential biases resulting from aggregation across racial and ethic groups, technical problems with the specification of the regression model, and selection bias, which he considers to be more problematic than initially acknowledged by Putnam. Furthermore, he argues that Putnam fails to provide any explanation that might explain his most controversial finding, that 'diversity leads to lower trust in both the in-group and out-groups' (Dawkins 2008). It is important to note, however, that Putnam's data only indicate this antagonism between diversity and social trust in the short-term, the argument being that this antagonism is amenable to change in the long-run. At the same time, in the absence of any empirical evidence, this argument is more speculative than definitive.

Alongside these weaknesses, there are problems inherent in extrapolating research findings from the United States to elsewhere (Giddens, 2007).

Putnam's hypothesis has stimulated much debate since its first formulation, not least because it appears to oppose directly the contact hypothesis. Taking account of this, we set out to explore inter-group relations in three Northern Ireland neighbourhoods with roughly similar proportions of Protestant and Catholic residents. Analysing the extent and nature of cross-group 
contact experienced by residents, and the prevailing social climate, we examine responses to the 'other community'.

\section{The Empirical Studies}

The three areas selected for this study are amongst the most ethnically mixed in Northern Ireland according to the most recently available 2001 census data. The first area, A, is situated in Limavady and has an estimated population of 1679: 49 per cent Protestant and 49 per cent Catholic. The area was ranked 78 out of 890 wards on the 2005 Northern Ireland Multiple Deprivation Measure, positioning it within the 'most deprived 10 per cent' band. The second mixed community, B, is in Ballymena and has a population of approximately 2611: 49 per cent Catholic and 46 per cent. Area B was the 118th placed ward on the Nobel indicator for multiple deprivation. The area falls just outside the top 10 per cent most deprived wards and is ranked within the 'most deprived 20-30 per cent' band. The last area, $\mathrm{C}$, is situated in South Belfast and has an estimated population of 5115: 58 per cent Catholic and 37 per cent Protestant. Area C was ranked 429th for multiple deprivation. The statistics reflect class disparities between the first two areas and area $\mathrm{C}$, highlighting the complexity of the relationship between class, community and ethnic identity. It is important to bear in mind, however, that statistics that are expressed at ward level can be misleading, suggesting greater heterogeneity than actually exists: during data collection we found evidence of segregation on a block-by-block, and street-bystreet basis within these apparently 'mixed' communities.

Data were primarily collected during in-depth semi-structured interviews with residents of these neighbourhoods. In each area access to individuals was 
gained through community groups and organizations, then through a process of snowball sampling; fifteen interviews were undertaken in each location (45 in total). The age of our interviewees ranged from 16 to 91 and the majority of those interviewed were female; this was not a deliberate policy, it was simply that women appeared to be more willing to be interviewed. It is possible that the sample drawn from this form of recruitment represents a particular sub-section of the population in each area. This should be taken into consideration when assessing the views presented. At the same time however, this method provided a means of entry to a sample that we would otherwise have difficulty accessing. The area in which respondents were drawn was taken as an indicator of social class. The interviews dealt with social identity; community membership and association; contact with, and experience of, the other community; and owngroup/other-group attitudes and responses.

\section{Findings}

The themes emerging from our data are generally consistent with the contact hypothesis, supporting the contention that positive contact between members of divided groups can reduce anxiety and promote better inter-ethnic relations. There is, however, also some support for Putnam's argument that ethnically mixed environments can encourage 'hunkering down', which compromises interethnic trust. Having said that, our data challenge Putnam's argument that these responses are a consequence of 'anomie' or 'social malaise'. Instead, our interview material indicates that withdrawal from social activity in the neighbourhoods we researched was a calculated response at times of threat, often intended to protect positive inter-ethnic relations. Related to this, we offer an 
interpretation of own-group and other-group trust that relates to the local character of direct and indirect contact between Protestants and Catholics.

Dealing first with evidence in support of contact theory, the following section considers the nature and extent of inter-ethnic relations in area A, B and $\mathrm{C}$, the value of cross-ethnic relationships in challenging stereotypes and promoting mutual understanding, and the mediating processes that seem to generate the positive contacts that encourage empathy and trust. Finally, we consider the implications of our findings for Putnam's theory, particularly as they relate to his arguments about alienation and isolation in ethnically diverse contexts.

\section{Contact and inter-ethnic relationships}

Interviewees, without exception, had inter-ethnic social relationships, which were often strong ties that had developed as a consequence of sustained and intimate contact. In the majority of cases, respondents identified some close friends and/or family members as being from the 'other' community. Indeed the proportion of those who were in a mixed marriage/relationship, or were the product of such a union, was proportionately much higher than the usual estimates of the prevalence of such unions in Northern Ireland. Maximum estimates regarding such relationships are typically between nine and ten percent (Niens et al. 2003). It was also clear that the opportunity for contact presented by a mixed environment was a facilitating variable in the development of these relationships. Some residents spoke of strong personal friendships with neighbours, some spoke of having met and forged friendships through 
community groups/activity, and some identified their neighbourhood as the place where they were able to 'really get to know' members of the other community.

In line with the results of a substantial body of empirical research on contact (Kenworthy et al. 2005), in our interviews self-disclosure and perspective-taking were highlighted as important processes in the development of inter-ethnic relationships. However, it appears that there is a temporal dimension to these processes. For example, a Protestant woman, speaking about relationships that she had developed with Catholic women in her neighbourhood, alluded to the well-documented avoidance norms that often characterise interethnic relations in Northern Ireland during the early stage of contact (Shirlow and Murtagh 2006).

When you get comfortable with people after you know them for a while you can start to talk about politics and religion and stuff. It wouldn't be appropriate to talk about religious beliefs or how you think about things when you meet someone for the first time. (Female, Protestant, 49, area C).

She proceeded to describe how her friendships had reached the point where discussion of controversial issues was possible, and she gave examples of how ethnic stereotypes held by both her and her neighbours had been challenged: '...one of the things we could talk about was their view that because I was a Protestant I would be supportive of the Orange Parades'. Intimacy, characterised by self-disclosure and trust, was key to the exploration of potentially tensioninducing issues such as responses to loyalist parades. 
The strength of inter-ethnic ties and positive experiences of the other group was also evident in the mitigation that such relations seemed to offer when people in a mixed environment had negative or hostile experiences of the other group.

Q: To what extent is sectarianism a problem?

A: The highest. I would always be aware of it and try to keep my wits about me. It's just one of those things - you can't let your guard down. I don't feel completely safe. I was chased by a crowd of masked men. Apparently they were UYM (Ulster Young Militants) that had come up to the estate from Harryville. But I have Protestant neighbours and they have been brilliant. (Male, Catholic, 23, area B)

In areas $\mathrm{A}$ and $\mathrm{B}$, the latter a place where sectarian attacks are common and there appears to be an ever-present sense of danger and threat, it is noteworthy that positive relationships not only flourish, but seem to moderate the impact of hostile, sectarian experiences. One woman, who had moved to a mixed street from an area of the estate where she and her family had been subject to sustained sectarian abuse and attacks (including having the family car shot at), described how the support she had from (other-group) friends and family underpinned her commitment to remaining in a mixed environment. A key dimension of the mitigating effect of positive inter-ethnic contact is respondents' ability to 
differentiate between 'good' and 'bad' within their own and the other community, thereby allowing more nuanced understandings of each:

To me there are two types of Protestant and two types of Catholic.

Catholics and Protestants who want to get on with their lives and those who are bitter and want to cause trouble. (Male, Catholic, 23, area B)

This more critical and 'objective' stance has been highlighted by other research on contact, which points to a greater tendency for people in segregated environments to homogenize the other group (Hughes et al. 2008). Explanations have focused on the idea that those living in segregated areas have few interethnic encounters and therefore have little knowledge of the diversity among other group members (Turner, Crisp and Lambert 2007). Shirlow's (2003) study of an interface area in North Belfast corroborates this viewpoint. Shirlow's research included interviews, where, amongst other characteristics, he distinguished between pensioners and non-pensioners, and sectarians and nonsectarians. Among the former group, it was found that majority of pensioners had a history of cross-community relationships, forged prior to, and maintained through the recent conflict. Under these circumstances and consistent with our data on the effects of contact, Shirlow (2003) noted a greater propensity to concede the involvement of both communities in sectarian behaviour. Similar findings were observed among the non-sectarian group who were also capable of rationalising the reasons for Catholic and Protestant animosity towards each other. This is in contrast to the sectarian group where the conflict is 
unequivocally understood through 'a uni-dimensional ethno-sectarian logic' (Shirlow 2003, pp. 86).

We also found that recognition of the variability of 'goodness', based on experiences of members from both own and other groups, informed willingness to trust:

There's an element on both sides that I wouldn't trust, but the majority of decent, honest Protestants and Catholics I would trust. (Male, Catholic, 70, area C)

This discerning attitude also extended to analyses of 'own-group' culture and tradition, where the ability to understand the perspective of the other, generated by close relationships with members of the other group, led to a reassessment of own-group cultural norms and values, which might otherwise not have been challenged:

At the local Primary school they were having an exhibition to celebrate a big anniversary. My eldest son was at the school and my husband and I went up to see the exhibition. There was a lot of Royal photographs and red, white and blue I thought. It was really the first time that I ever went into that school and thought of it as a Protestant school, not a State school. It really projected things from one side of the community and not the other. (Female, Protestant, 49, area C). 
This woman is currently married to a Catholic. Her previous husband was a Protestant and children from her first marriage attended the school in question. She describes her perceptions as having been modified by the relationship with her second husband and his family and friends, casting a new light on taken-forgranted aspects of her own culture, which she has come to see as denigrating the culture and tradition of the other community. The reference she makes to the school as 'Protestant' rather than 'state', reflects a long running debate about the status of state-controlled schools that claim a 'Christian' rather than a specifically Protestant ethos (Wardlow 2006).

In some cases, the more critical position evident in the above analysis also extended to an apparently more objective and moderate understanding of the orientations of Protestants and Catholics towards sectarianism and the conflict:

\footnotetext{
Catholic people definitely have higher tolerance of other people and races who are different. I feel that Protestant people feel threatened [by other groups]. It is not through badness, it is through fear. It is through fear of things changing. The fear that they are going to lose a grip on stuff or that somehow life will be awful for them. My heart goes out to them, but you have to look back and think how awful it must have been the other way round. (Female, Protestant, 46, area C).
}

This woman attributes positive characteristics to the other group, and, while acknowledging the sense of fear in her own community, contextualises it by referencing the pain that had been experienced by the other group on the 
receiving end of discrimination. The ability to empathise with the out-group has also been found in other studies of inter-ethnic contact (Batson et al 1997).

Finally, in these mixed communities we found a strong appreciation of different cultural traditions and the need to celebrate diversity, to the extent that some residents were willing to participate in, or lend support to, the staging of events/celebrations that are normally associated with the other community:

Everybody in this street [i.e. Catholic and Protestant] would celebrate the Twelfth of July. It's not about religion. It's just a bit of craic (Female, Catholic, 40s, area A).

This readiness to engage in 'other-group' celebrations was more apparent in area $\mathrm{A}$ and $\mathrm{B}$, where such events occur more frequently. (In the more affluent areas, like area $\mathrm{C}$, cultural celebrations and obvious expressions of identity are quietly discouraged (Shirlow and Murtagh 2006)). However, consistent with a more empathetic understanding of the other group, some interviewees acknowledged that such events could also be provocative, and were at pains to draw a boundary between 'acceptable' celebrations, and cultural displays that might threaten good relations:

I don't think there should be flags up all year. I don't think there's any need, it's to do with sectarianism. Sports wise, certainly, Saint Patrick's Day, certainly, Twelfth of July, certainly. Each side has their own fun...but for other times of the year, I don't think there's any need. I think it makes people ill at ease and people can't live properly with it. (Male, Catholic, 46, area A). 
This respondent is voicing a widely held view that flags not removed after an acceptable interval following an event, can transform in a community psyche from legitimate and acceptable cultural expression, to territorial markers that symbolise a power struggle, as one community seeks to assert its dominance over the other (Jarman and Bryan 1998). The appeal to boundary maintenance in the above quotation is made with a view to preserving the positive relations that currently exist between the two communities. At the same time, it challenges the avoidance culture in Northern Ireland that seeks to neutralise mixed environments (Hughes et al. 2008).

This section has presented qualitative data that lend weight to the argument that contact, particularly when it is sustained and close, may ameliorate anxiety and lead to more respectful and empathetic understandings of the ethnic Other. In the next section, we explore data from these ethnically mixed communities in the context of Putnam's argument that diversity equates with 'hunkering down' and diminished social capital. We also raise some conceptual questions about what it actually means to trust, and particularly to trust ethnic others, in situations of ethnic diversity.

\section{Diversity in mixed neighbourhoods}

Like Putnam, we used census data to define the most ethnically mixed wards in Northern Ireland when selecting our case study areas. Unlike him, however, our qualitative approach was keen to explore 'personally defined' neighbourhoods, which exist in the lived experiences of residents. From this perspective, we found considerable variation in terms of opportunity for contact with the other 
community. Although in area $\mathrm{C}$ residents reported widespread mixing, area $\mathrm{B}$ and A are, demographically, patchworks of sectarian interfaces and mixing, sometimes on a street-by-street basis. Most residents have narrowly-defined spheres of affiliation, with many indicating an attachment to their immediate surroundings and the people within them, rather than to the estate or wider community:

There's no trouble in this area. I know there would be trouble across the street, but it never comes to this street. This street is mixed but across there it would be Catholic. (Female Catholic, 40s, area A)

Hence, at sub-ward level, which is not picked up by the census, there may be considerable variation in the extent of and opportunity for mixing. This finding reinforces a point made by Amin (2002) who, advising caution against statistical indictors of integration, argues that it is not inevitable that ethnic groups actually 'mix' in mixed areas. Although we focused on those who had a significant degree of contact with the other community, it was clear that many in area B and A had limited opportunity for contact and, living at what are effectively minisectarian interfaces, had generally hostile experiences of the other community. In his work, Putnam recognises the potential difficulty in using the census tract as a proxy for 'neighbourhood':

The real neighbourhoods in which people experience their daily lives likely vary from census tracts. Obviously no nationwide survey could 
gather contextual data on personally defined "neighbourhoods" for all respondents, so it is difficult to address this issue empirically. (2007: 10)

However, Putnam goes on to argue that, insofar as the error introduced by the mismatch between objectively and subjectively defined neighbourhoods is more or less random, the net effect is that his results underestimate the real effects of diversity. Our data suggest, however, that neighbourhoods at sub-ward level are not just subjectively defined, they are objectively real and measurable alternative units of analysis that challenge the use of census tracts or wards as proxy measures of neighbourhood diversity. The fact that these alternative units are mixed or segregated is concealed by even small-scale aggregate census data, but has important implications for policy and planning, and for perceptions of the present state of peace and conflict in Northern Ireland. Not least, our understanding of 'sectarian interfaces' (Shirlow and Murtagh 2006) may require some considerable rethinking.

Our observation that in Northern Ireland neighbourhoods within census wards may be mixed or segregated, and experienced as such, challenges some of the assertions that Putnam makes on the strength of his argument that distinctions at this level are more or less irrelevant. The next section explores our data and Putnam's in relation to his arguments on the correlation between diversity, hunkering down, social capital and trust. The material we present is interpreted according to the subjective reality of neighbourhood experience as articulated by respondents. 


\section{'Hunkering down'}

Fear and sense of threat in the mixed areas that we studied can sometimes lead to 'hunkering down', described by Putnam as 'pulling in like turtle':

Community relations wouldn't be the best. There's a divide. I just don't bother with anybody because I don't want to get dragged into anybody else's business. I don't bother with anybody. I don't have conversations with anybody on the street. I just basically say hello. I would never stop to have a conversation with anybody about the way things are up the street...I just don't get into conversations with people. (Female, Protestant, 45, area A)

However, in direct contrast to Putnam, we found that this 'hunkering down' is often a temporary response to external events (such as, for example, sectarian attacks, the other group's parades and commemorations, or canvassing by political parties at election times). In this sense it is a device employed to preserve inter-ethnic relations that already exist, rather than, as in Putnam's argument, a consequence of the absence of such relations. In the above quotation the interviewee is married to a Catholic and reports many Catholic friends and family members.

Alongside some evidence of hunkering down, and in conflict with Putnam's finding that diverse communities are characterised by anomie and social isolation, we found considerable evidence of residents from mixed neighbourhoods who were willing to extend themselves or to take risks on behalf of friends and neighbours from the other community: 
This would be quite a close-knit community. Last year a number of youths put up Irish flags. Do you see the complaints I got, they were all from Catholics who didn't want to offend their Protestant neighbours. We have Protestants round here and some of them have lived here longer than us. They have a right to live and they have a right to live in peace. They shouldn't have to look out of their windows at flags. Believe it or not, that's what the case was. The Catholic residents wanted the flags down so as not to offend their Protestant neighbours. So between me and my daughter, and another girl we got the flags down. We spoke to the children and got a couple of older ones to help us - people who had grown out of all that carry on. We approached them and thy helped us talk to the children. So we got them taken down. We had to talk and talk. (Male, Catholic, 46, area A)

\footnotetext{
Efforts like these to tackle sectarianism and offensive behaviour were commonplace and are examples of drawing on social capital that exemplify norms of reciprocity and trustworthiness, which Putnam sees as intrinsic to the concept. Moreover, to use Putnam's term, they are manifestations of 'bridging capital' between Protestant and Catholic community members. This evidence for bridging social capital resonates with previous research that has explored the concept in Northern Ireland(see for example, Acheson and Milosky (2008); Cairns, Van Til and Williamson (2004); Campbell et al. 2008).

In contrast to Putnam's argument that ethnic diversity challenges social solidarity and inhibits social capital (2007: 2), our data suggest the possibility
} 
that in Northern Ireland, diversity, and its attendant inter-ethnic hostility, may, where relationships of trust have been established, encourage shared social action.

\title{
Inter-ethnic Trust
}

Putnam found lower levels of trust in diverse neighbourhoods. In contrast, we found that trust is a complex concept which cannot easily be measured by an item on a questionnaire that asks respondents to indicate 'how much' they trust members of other (ethnically-defined) groups. The following interview extract reveals the multilayered dimensions of trust in an ethnically divided context:

\author{
Q: Thinking about your close friends what factors would you consider \\ important in terms of friendship?
}

\begin{abstract}
A: Well religion doesn't figure at all. Things like loyalty and shared interests and something in common. Sense of humour...Someone who I trust.
\end{abstract}
Q: You mentioned trust. Do you think you can trust a Protestant and a Catholic equally?

\begin{abstract}
A: To be honest, I'm not sure. I guess there's probably part of me that trusts Catholics more, either because I know them better or I know their background better. I mean I couldn't deny that's true. It's not a huge part but there is that kind of wee notion that I understand the Catholic better. For instance take a Protestant and a Catholic friend of mine...I kind of
\end{abstract}


understand the Catholic better because I understand, well I feel I understand their experiences more than I understand the Protestant experiences....but it wouldn't be trust in that I wouldn't trust their [Protestant friend] advice or I wouldn't trust them to look after my children. It would be more, kind of, trust of their interpretation of something. I would probably be more inclined to trust the Catholic version of something over the Protestant version if I had to make a choice. I guess there is always going to be that difference of backgrounds that may become an issue under certain circumstances. (Female, Catholic, 34, area C).

This woman articulates subtle differences in the trust that she might have for Protestant and Catholic friends. Hence, whilst she would trust Protestant friends to look after her children, she might be less inclined to trust their interpretation of an event or issue that relates to inter-ethnic division in Northern Ireland. Her reference to the fact that differences in background may become an issue under certain circumstances resonates with the views of other respondents. Some of those who claimed to trust implicitly their friends from the other group also stated that at times of threat from the other group, trust could be challenged.

These data suggest a relationship between perception of trust and identity salience: where cross-cutting, non-ethnic identifications are prioritised (such as female, mother, carer, friend) trust is implicit. However, when ethnic identifications become salient, trust responses are more variable and conditional. In asking his respondents to indicate how much they trust whites, blacks, Hispanics etc., Putnam is unlikely adequately to capture the levels of trust that may exist in circumstances where ethnicity is not the most salient consideration. 
Finally, Putnam found lower levels of own-group and other-group trust in ethnically diverse communities. Our research also suggests the possibility that trust levels might be generally lower in mixed communities. However, there is little evidence in our data that this might be attributable to disengagement or anomie. Rather, as noted above, we found respondents to be more discerning about who they trusted in both their own and the other community because experience of both groups in the divided context underlined the perceived potential within each group for good and bad.

\section{Conclusion}

Our data lend support to the idea that opportunities for sustained and intimate contact afforded by an ethnically mixed context have implications for promoting 'better' inter-ethnic relations. In sum, and consistent with a significant and growing body of empirical and theoretical literature, we find evidence that sustained inter-ethnic contact, can promote perspective taking and acceptance of and respect for difference. We also found that residents who reported significant inter-ethnic contact also demonstrated 'other-group empathy' and a more critical and nuanced response to both their own and the other group. One manifestation of these positive 'contact effects' can be seen in the support received by victims of sectarianism from members of the other group, and in the willingness of people to extend themselves on behalf of Others. Hence, rather than weak social capital characterising mixed neighbourhoods, our data at the sub-ward level suggest that positive inter-ethnic relations, in the context of an ethnically-divided broader social context, may serve to galvanize some people to action that challenges sectarianism and inter-ethnic hostility; in Putnam's words, 
'Enabling...participants to accomplish goals they could not accomplish without that network' (2007: 138).

More generally, though, the response to inter-ethnic tension is to withdraw; 'keeping yourself to you' is the Northern Ireland colloquial equivalent of Putnam's 'pulling in like a turtle'. However, although the response is the same in each case, our data suggest that it may have other antecedents and causes. 'Hunkering down' in Northern Ireland is more often a calculated response to threats that emanate from beyond the boundaries of the mixed neighbourhood, than a consequence of social malaise or anomie. It seems - and this may be to state the obvious - that more positive inter-ethnic relations are more likely to prosper in non-threatening situations and/or when the particular threat has been removed. A more significant issue in the Northern Ireland context may be the nature of threat in the eyes of its victims; understanding this is likely to be important for efforts to ameliorate ethnic conflict and division in a lasting fashion.

Finally, there is some continuity between our argument and Putnam's 'constrict' theory, in that residents of our mixed neighbourhoods showed themselves to be discerning about who they trust. In particular, they appear to be less trustful of 'own-group' members than might be expected. Diversity does, indeed, seem to have a moderating effect on trust relations in some circumstances. In trying to interpret this, we speculate that in neighbourhoods where segregation and mixing occur on a street-by-street basis, residents may be more attuned to the potential for positive and negative inter-ethnic relationships and responses. In this respect, it could be that negative experiences of 'unknown' other-group members are tempered by supportive relationships with 
other-group friends and neighbours. Similarly, witnessing sectarian acts perpetrated by members of one's own group on other-group friends may undermine trust in one's own group.

Our data also suggest that we should not assume a blanket trust response towards the other group that applies in all situations. In harmony with contact theory, we observed that when cross-cutting identities based on common interests (for example, community development, sports, arts etc) or shared roles (for example, mother, social club member, community worker etc) became salient, negative trust, which was apparent when divisive identities were salient, diminished somewhat. Interestingly, Putnam himself acknowledges the power of 'reconstructed' identities to break down ethnic tensions:

In particular, it seems important to encourage permeable, syncretic, 'hyphenated' identities; identities that enable previously separate ethnic groups to see themselves, in part, as members of a shared group with a shared identity. (Putman 2007: 161)

Whilst Putnam accepts that cross-cutting identities and 'superordinate' group goals promote better inter-ethnic relations, his explanation of the change process seems to conflict somewhat with his dismissal of the contact hypothesis. For example, 'reduced social distance' (p.159), the 'undoing of past segregation' (p.161), the relaxation of ethnic endogamy (p.162), and cultural assimilation (p.162) are all presented by Putnam as mediators of inter-ethnic trust and social capital in the US. He avoids the obvious questions of how and why these processes evolve: 'Recounting exactly how that happened would require another 
article longer than this one' (p.162). However, and accepting the complexity of ethnic change and the myriad of influencing factors (legislative change, policy intervention, the revision of social and cultural norms, etc.), there can be no question that inter-ethnic contact is a contributory factor. To state the obvious, for example, increased inter-ethnic marriage (explicitly mentioned by Putman) is unlikely to have happened in the absence of intimate relationships between members of different ethnic groups who, at some level, acknowledge their ethnic group memberships.

Our data, although small-scale, suggest a possible alternative to Putnam's argument that ethnic diversity causes lower trust and encourages 'hunkering down'. Instead, in a shift of emphasis, we argue that, rather than being an obstacle to increased inter-ethnic contact, lower trust and social withdrawal may actually be a necessary consequence of it. Nor do we see more discerning trust responses and withdrawal from potentially conflictual situations as necessarily negative strategies; rather, they may be ways of protecting inter-ethnic relationships that already exist.

Finally, Putnam found that, in general, civic engagement and social capital are negatively correlated with ethnic diversity. One notable exception, when social capital did appear to be higher in diverse neighbourhoods, was attachment to social reform groups. Again, this harmonises with our evidence about Catholic and Protestant neighbours and friends demonstrating commitment to tackling division and sectarianism through cross-community effort. Without wishing to labour the point, such initiatives are often borne of positive contact.

According to Putnam, other measures of social capital are lower in ethnically-diverse areas; this may also be true in Northern Ireland's mixed 
neighbourhoods. For example, the reality of sectarian micro-interfaces in apparently mixed neighbourhoods (where mixed and segregated streets exist side-by-side) may make 'community' activity risky and is likely to militate against the kind of collective activity that is perhaps characteristic of more ethnically homogenous neighbourhoods. Similarly, residents of divided areas in Northern Ireland are indeed likely to perceive a lower quality of life and experience less happiness (cf. Putnam 2007: 150), as they are faced with an ongoing sectarian threat to their own safety and that of their property (Jarman 2005).

Interestingly, the implications of our findings for public policy in Northern Ireland differ little in essence from Putnam's proposals for encouraging a 'successful immigrant nation' in America. Indeed, the central tenets of his argument seem very apposite in Northern Ireland and, taken together with a political settlement and equality legislation, could easily offer a template for relationship building during the transition from conflict to peace. To summarise, he advocates the strengthening of shared identities, the creation of more opportunities for meaningful interaction across ethnic lines, national aid to the most divided communities, and the promotion of 'bonding social capital' (referred to as 'single identity work' in Northern Ireland) as a prelude to the development of secure 'bridging social capital'. In other words, he is arguing for the encouragement of relatively safe and stable inter-ethnic contact as part - and only part, it should be emphasised - of a long-term strategy of political and social change. So are we. 
JOANNE HUGHES is a Professor in the School of Education at Queen's

University.

ADDRESS: School of Education, Queen's University, Northern Ireland, UK.

Email: joanne.hughes@qub.ac.uk

\begin{abstract}
ANDREA CAMPBELL is a Lecturer in the School of Psychology at the University of Ulster.
\end{abstract}

ADDRESS: School of Psychology, University of Ulster, Magee Campus, Northern Ireland, BT48 7JL, UK. Email: AC.Campbell1@ulster.ac.uk

RICHARD JENKINS is a Professor in the Department of Sociological Studies at Sheffield University.

ADDRESS: Department of Sociological Studies, University of Sheffield, UK.

Email: r.p.jenkins@shef.ac.uk 


\section{'References'}

ACHESON, NICHOLAS and MILOFSKY, CARL 2008 'Peace building and participation in Northern Ireland: Local social movements and the policy process since the Good Friday Agreement', Ethnopolitics, vol. 7, no. 1, pp. 63-80

ALLPORT, GORDON 1954 The nature of prejudice, Reading, MA: Addison Wesley

AMIN, ASH 2002 'Ethnicity and the multicultural city: living with diversity', Environment and Planning A, vol, 34, no. 1, pp. 959-980

BATSON, DANIEL and EARLY, SHANNON and SALVARANI, GIOVANNI 1997 'Perspective taking: Imagining how another feels versus imagining how you would feel', Personality and Social Psychology Bulletin, vol. 23, pp. 751758

CAIRNS, ED and VAN TIL, JON and WILLIAMSON, ARTHUR 2004 'Social capital, individualism and community background in Northern Ireland', A report to the Office of the First Minister and Deputy First Minister and the head of the Voluntary and Community Unit of the Department for Social Development, Centre for Voluntary Action Studies, University of Ulster

CAMPBELL, ANDREA. et al. 2010 'Social capital as a mechanism for building a sustainable Northern Ireland', Community Development Journal, vol. 45 , no. 1 , pp. $22-38$ 


\begin{abstract}
COMMUNITY RELATIONS COUNCIL 2010 'The Community Relations
Council condemns the violent disturbances around parades and protests'.

Available online at: http://www.community-relations.org.uk/about-us/pressreleases/item/164/the-community-relations-council-condemns-the-violentdisturbances-around-parades-and-protests/ (accessed 9 August, 2010)
\end{abstract}

DARBY, JOHN 1990 'Intimidation and interaction in a small Belfast community: The water and the fish', in John Darby and Nicholas Dodge and Anthony Hepburn (eds), Political violence. Ireland in a comparative perspective, Belfast and Ottawa: Appletree Press, University of Ottawa Press, pp. $83-102$

DAWKINS, CASEY 2008 'Reflections on diversity and social capital: A critique of Robert Putnam's “E Pluribus Unum: Diversity and community in the twenty-first century the 2006 Johan Skytte prize lecture', Housing Policy Debate, pp. $208-217$

DOVIDIO, JOHN and GAERTNER, SAMUEL and KAWAKAMI, KERRY 2003 'Inter-ethnic contact: The past, present, and the future', Group Processes and Inter-ethnic Relations, vol. 6, pp. 5-21

GAERTNER, SAMUEL and DOVIDIO, JOHN 2000 Reducing inter-ethnic bias: The common ingroup identity model, Philadelphia, PA: Psychology Press 
GAERTNER, SAMUEL. et al. 1993 'The common ingroup identity model:

Recategorisation and the reduction of inter-ethnic bias' in Wolfgang Stroebe and

Miles Hewstone (eds), European Review of Social Psychology New York:

Wiley, vol. 4, pp. 1-26

GIDDENS, ANTHONY 2007 'Doubting diversity’s value', Foreign Policy, November / December, pp. 86-88

HEWSTONE, M and BROWN, RUPERT 1986 'Contact is not enough: An inter-ethnic perspective on the 'contact hypothesis', in Miles Hewstone and Rupert Brown (eds), Contact and conflict in inter-ethnic encounters, Oxford, UK: Basil Blackwell

HEWSTONE, MILES. et al 2004 'Inter-ethnic contact in a divided society: Challenging segregation in Northern Ireland', in Dominic Abrams and Jose Marques and Michael Hogg (eds), The social psychology of inclusion and exclusion, Philadelphia, PA: Psychology Press, pp. 265-292

HUGHES, JOANNE. et al. 2008 'What's there to fear? - A comparative study of responses to the out-group in mixed and segregated areas of Belfast', Peace and Change, vol. 33, no. 4, pp. 522-548

HUGHES, JOANNE and DONNELLY, CAITLIN 2003 'Community relations in Northern Ireland: A shift in attitudes?', Journal of Ethnic and Migration Studies, vol. 29 , no. 4 , pp. $643-661$ 
JARMAN, NEIL 2005) 'No longer a problem? Sectarian violence in Northern Ireland', Institute for Conflict Research

JARMAN, NEIL and BRYAN, DOMINIC 1998 'From riots to rights:

Nationalist parades in the North of Ireland', Centre for the Study of Conflict, University of Ulster, Coleraine

KENWORTHY, JARED 2005 'Inter-ethnic contact: When does it work, and why?', in John Dovidio and Peter Glick and Laura Budman (eds), On the nature of prejudice fifty years after Allport, Malden, MA: Blackwell, pp. 278-292

KNOX, COLIN 2008 'Policy making in Northern Ireland: Ignoring the evidence', Policy and Politics, vol. 36, no. 3, pp. 343

KNOX, COLIN and HUGHES, JOANNE 1996 'Crossing the divide: Community relations in Northern Ireland', Journal of Peace Research, vol. 33, no. 1 , pp. $83-98$

MCAULEY, JAMES and TONGE, JONATHON 2009 'Britishness (and Irishness) in Northern Ireland since the Good Friday Agreement', Parliamentary Affairs, pp. 1-20

NIENS, ULRIKE and CAIRNS, ED and HEWSTONE, MILES 2003 'Contact and conflict in Northern Ireland', in Owen Hargie and David Dickson (Eds), 
Researching the troubles: Social science perspectives on the Northern Ireland Conflict, Edinburgh: Mainstream Publishing, pp. 123-140

PETTIGREW, THOMAS 1998 'Inter-ethnic Contact: Theory, research and new perspectives', Annual Review of Psychology, vol. 49, pp. 65-85

PAOLINI, STEFANIA 2004 'Effects of direct and indirect cross-group friendships on judgements of Catholics and Protestants in Northern Ireland: The mediating role of an anxiety-reduction mechanism', Personality and Social Psychology Bulletin, vol. 30, pp. 770-786

PUTNAM, ROBERT 2007 'E Pluribus Unum: Diversity and Community in the twenty-first century. The 2006 Johan Skytte Prize Lecture', Scandinavian Political Studies, vol. 30, no. 2, pp. 137-174

SHIRLOW, PETER 2003 'Ethno-sectarianism and the reproduction of fear in Belfast', Capital and Class, vol. 80, pp. 77-93

SHIRLOW, PETER and MURTAGH, BRENDAN 2006 Segregation, violence and the city, London: Pluto Press

STEPHAN, WALTER and STEPHAN, COOKIE 1985 'Inter-ethnic anxiety', Journal of Social Issues, vol. 41, pp. 157-176 
TURNER, RHIANNON and CRISP, RICHARD and LAMBERT, E 2007

'Imagining inter-ethnic contact can improve inter-ethnic attitudes', Group

Processes and Inter-ethnic Relations, vol. 10, no. 4, pp. 427-441

WARDLOW, MICHAEL 2006 'Sharing not separation’, Northern Ireland

Council for Integrated Schools 